Cambridge Archaeological Journal

http://journals.cambridge.org/CAJ

Additional services for Cambridge Archaeological Journal:

Email alerts: $\underline{\text { Click here }}$

Subscriptions: $\underline{\text { Click here }}$

Commercial reprints: Click here

Terms of use : Click here

CAMBRIDC

ARCHAEOLOGICAL

JOURNAI

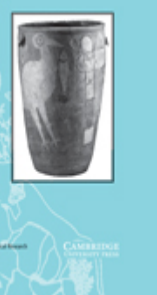

Contested Objects: Material Memories of the Great War, edited by Nicholas J. Saunders \& Paul Cornish, 2009. Abingdon: Routledge; ISBN 978-0-415-45070-6 hardback $£ 75 \&$ US\$120; xx+311 pp., 87 figs.

Gabriel Moshenska

Cambridge Archaeological Journal / Volume 20 / Issue 02 / June 2010, pp 279 - 281

DOI: 10.1017/S0959774310000363, Published online: 10 June 2010

Link to this article: http://journals.cambridge.org/abstract_S0959774310000363

How to cite this article:

Gabriel Moshenska (2010). Cambridge Archaeological Journal,20, pp 279-281 doi:10.1017/S0959774310000363

Request Permissions : $\underline{\text { Click here }}$ 
Contested Objects: Material Memories of the Great War, edited by Nicholas J. Saunders \& Paul Cornish, 2009. Abingdon:

Routledge; ISBN 978-0-415-45070-6 hardback $£ 75$ \& US\$120; xx+311 pp., 87 figs.

\section{Gabriel Moshenska}

For anyone interested in the ways in which conflict and violence have shaped the modern world this book is a box of delights; a refreshingly diverse collection of papers reaching beyond archaeology and anthropology to history, art history, geography and museum studies. Contested Objects is based on a conference held at the Imperial War Museum, London in 2004, the second in a series of conferences examining the material culture of modern conflict. The first two conferences focused on the First World War from a global perspective, later events have broadened their scope to incorporate twentieth-century conflict in the broadest sense. The first published volume, Matters of Conflict (Saunders 2004) set an ambitious theoretical agenda for the interdisciplinary study of modern conflicts under the aegis of material culture anthropology, building on Saunders's previous work on trench art (Saunders 2003). In this latest volume the editors restate their intention to create 'a transformation in our understanding of modern conflict, its varied legacies and its potent lessons' (p. 7).

The breadth of coverage across the 20 chapters of this book is impressive, both in its thematic scope and its geo-

CAJ 20:2, 279-81 $\quad$ C 2010 McDonald Institute for Archaeological Research doi:10.1017/S0959774310000363 
graphical range. For a British reader it is a valuable reminder that the First World War extended far beyond the mud of the Western Front to the deserts of Iraq and the Middle East, the Italian Alps, East and West Africa and the cold waters of the Atlantic. At the same time we are repeatedly drawn away from the battlefields to the Home Front, a similarly important reminder of the wider contexts within which the war was waged.

In focusing on material culture it is inevitable that several of the chapters examine what have become material icons of the conflict: the ubiquitous Commonwealth War Graves Commission headstone; the campaign medals awarded with an apparent bewildering lack of consistency; and the German steel helmet. Gygi follows the life history and the rich symbolic afterlife of this fearsome item, now most commonly associated with the Nazis but also, as he shows, appropriated for a range of uses by Saddam Hussein, George Lucas and the Hell's Angels.

The unifying focus on material remains has allowed the authors and editors to examine some of the more esoteric and marginal episodes of the conflict: for example the impact of the First World War on the growth of Freemasonry was, I must confess, entirely unknown to me. Dennis's paper describes the formation of ad hoc Masonic lodges in various conflict zones, many of which recycled available war materials such as shell nose-caps to create the formal lodge fittings and Masonic 'jewels'. Black's paper describes how heavy losses of shipping in the U-Boat war encouraged naval commanders to experiment with bizarre forms of camouflage, the zebra-like 'Dazzle Ships'. These employed carefully formulated distortions of perspective, based in part on the pre-war 'Vorticist' art movement, to confuse U-Boat commanders as to the direction of the ship: their success, as Black discusses, was questionable. Waller's discussion of war memorials, the memories and experiences of war in British and German colonies in Africa describes a fascinating aspect of the conflict of which I was hitherto shamefully unaware. This chapter offers a fascinating new perspective on the ways in which service in the colonizers' armies affected indigenous social and economic identities and practices.

The last four chapters of the book are more traditionally archaeological examining, inter alia, British training landscapes and the strikingly well-preserved artefacts recovered from Alpine glaciers on the Italian front. Brown's paper on the recovery and identification of human remains from the Western Front examines the multitude of issues this practice raises, including the emotional and ethical dimensions. However I was not entirely comfortable with the photographs of the skeletal remains in situ: given that we now know some of their names and family connections there is a certain brutality in exposing these images to public view.

Two papers in particular highlight the extraordinary insights into the conflict that emerge from a material culture perspective. In the first, Dendooven examines the remarkable phenomenon of the apparent flood of donations to the In Flanders Fields Museum in Ypres. Allied soldiers billeted amongst the ruins of the city for weeks or months passed the time scavenging in the ruins of buildings collecting (or looting) a variety of objects including fragments of the stained glass windows. As Dendooven describes, many of these items are now making a return journey to the city, as descendents of servicemen bring or post them back. There are several different motivations that he identifies for this practice: a recognition that it was wrong to have taken the object in the first place, or a desire to return a fragment to its rightful home. Most interestingly there appears to be a hope that by donating an object to a museum, along with documents or a story relating to the relative who kept it,

the donor can be sure that the object will be preserved in theory for eternity, and in good condition. Moreover, if the object is properly catalogued, not only will the object survive, but also the 'proper' interpretation of that object, and the memory of that dearly loved person who had turned it into a war souvenir. (p. 66)

The analogous relationship of objects and memory narratives fragmented and reformed is a powerful and pervasive one.

The second paper of particular note, and one that demonstrates to brilliant effect the analytical potential of the multidisciplinary approach to material culture, is Phillips's study of the 'trench club', a category of improvised weapon used in hand-to-hand combat during trench raids. As Phillips notes, 'although the Great War is commonly acknowledged as a war of industrialized technology, the trench club is essentially a medieval weapon, and so, in a sense, an anachronism' (p. 46). Phillips establishes a detailed but sensibly elastic typology for these clubs, which ranged from the stereotypical lump of wood with nails in it to artistically carved knobkerries and mass-produced metal-headed maces. In examining these objects five distinct themes emerged: 'recycling, regression, trench art, the representation of trench clubs in British museums, and the British class system' (p. 53).

Phillips describes a club in the collection of the Imperial War Museum formed from the leather-wrapped sawn-off barrel of a German MGO8 machine gun: the perfect illustration of the regression from modern technological to medieval warfare, and an example of what the historian David Edgerton has called the 'creolisation of technology' $(2006,85)$. Phillips argues that the predominance of German clubs in British war museums was intended to portray the Germans as more barbaric fighters, and implies that British clubs may have been excluded from collections as well as from photographs and written accounts. The revival of the club highlights other medieval aspects of the First World War such as the system of trenches and the practice of mining under enemy positions: together with the spear-like fixed bayonet the trenches of the Western Front begin to resemble two opposing sieges on non-existent citadels.

It is a pity that this book is only available as a hardback, when Matters of Conflict had been a relatively affordable and more attractively designed paperback with larger and clearer type as well as a higher quality of image reproduction. This raises the question of whether it is worth spending $£ 75$ on this volume: no doubt the publishers are aiming for the academic library market. This is a dirty if familiar strategy of some larger publishers, understandable perhaps in the case of highly specialized works with very short print runs, but surely not appropriate for highly 
readable works on such a widely popular subject as this.

The study of modern conflict through its material remains is clearly a fruitful and exciting field, and future volumes in this series looking to later conflicts can only enhance this. A few chapters in this volume, such as Isyanova's study of trench-art collectors, suggest that it may also produce innovations in material culture theory. With such a vast and diverse range of topics to choose from it will be surprising if more ground-breaking work with far-reaching theoretical and practical applications did not emerge from this fertile patch of interdisciplinary study. In their foreword the authors suggest that the richest potential may lie in the numerous war museums of the world, 'many of which are the repositories of objects and memories that have lain dormant for the best part of a century' (p. xx); I look forward to the next stage of their awakening.

Gabriel Moshenska

UCL Institute of Archaeology

31-34 Gordon Square

London

WC1H OPY

UK

Email g.moshenska@ucl.ac.uk

\section{References}

Edgerton, D., 2006. The Shock of the Old: Technology and Global History since 1900. London: Profile Books.

Saunders, N.J., 2003. Trench Art: Materialities and Memories of War. Oxford: Berg.

Saunders, N.J. (ed.), 2004. Matters of Conflict: Material Culture, Memory and the First World War. Abingdon: Routledge. 